\title{
FAKTOR BI RATE, INFLASI DAN KURS RUPIAH TERHADAP PEMBIAYAAN KREDIT UMKM
}

\author{
Steven, Felicia Celesta, Silvia, Yeni Ariesa* \\ Program Studi Manajemen Fakultas Ekonomi, Universitas Prima Indonesia \\ yeniariesa@unprimdn.ac.id
}

\begin{abstract}
Currently, in developing countries, MSMEs have a big contribution to grow the community's economy, including Indonesia. MSMEs hold an essential position in economic progress. There are still very few researchers who examine the BI Rate, Inflation, and the Rupiah Exchange Rate on MSME credit financing. So, researchers are interested in taking this title. This study is an explanatory research which aims to describe the causal correlation between variables through hypotheses and is carried out through descriptive analysis. The population in this study is all MSMEs in Indonesia that receive credit financing. The data taken is the period 2011-2019. Population data collection techniques are carried out using a time series approach using an annual scale. The result is that the BI Rate, Inflation and the Rupiah Exchange rate partially have no effect and are not significant on MSME credit financing. Meanwhile, the BI Rate, Inflation, and the Rupiah Exchange simultaneously have a significant effect on MSME credit financing.
\end{abstract}

Keywords: BI Rate, Inflation, Rupiah Exchange, MSME Credit Financing

\section{PENDAHULUAN}

\section{I.1 Latar Belakang Masalah}

Saat ini, Di negara berkembang UMKM memiliki kontribusi yang besar untuk menumbuhkan perekonomian masyarakat, termasuk Indonesia. UMKM memegang peran penting dalam kemajuan perekonomian. UMKM juga mampu menyerap tenaga kerja dan produktif untuk menghasilkan tenaga kerja yang baru serta mampu pula menambahkan unit usaha yang dapat mendorong penghasilan rumah tangga dari bisnis itu, UMKM mampu menyerap tenaga kerja hingga 97\%. Terdapat 56,4 juta UMKM di indonesia baru sekitar 30\% yang dapat mengakses pembiayaan, sekitar 76,1\% memperoleh kredit dari bank, serta sekitar 23,9\% mengakses dari koperasi yang mencakup bisnis simpan pinjam non bank.

Dari sekian berlimpah persoalan yang kerap dijalani UMKM, sejumlah persoalan yang kerap berlangsung di UMKM sendiri ialah minimnya modal, pengelolaan keuangan yang tidak efisien, kurangnya inovasi, harga bahan baku tidak stabil, pembukuan masih memakai metode manual, manajemen waktu yang tidak teratur, distribusi yang tidak tepat dan tidak memiliki izin. Berhubungan bersama persoalan minimnya 
modal, UMKM memerlukan dorongan dari lembaga pembiayaan yang kredibel seperti perbankan. Sejumlah capaian riset menyatakan ternyata akses sejumlah besar UMKM pada perbankan masih terbatas. Di Indonesia BI Rate yakni taraf suku bunga menjadi pijakan dalam menentukan suku bunga untuk kedit. $\mathrm{BI}$ rate merupakan suku bunga kebijakan yang merepresentasikan perilaku ataupun stance kebijakan moneter yang ditentukan BI dan di umumkan pada publik. BI rate yang tinggi tentu sangat memberatkan bagi sebagian besar debitur UMKM yang ingin meminjam pada bank. Berkaitan dengan masalah harga bahan baku yang tak konstan, melemahnya nilai tukar pada mata asing mempunyai dampak yang cukup besar pada perekonomian indonesia terutama bagi pelaku usaha UMKM yang menggunakan bahan baku impor sehingga membuat bahan baku produksi semakin mahal. Kondisi ini dapat berdampak langsung ataupun secara tidak langsung terhadap kondisi profit margin, yang nantinya akan berdampak pada modal yang sulit berkembang abhkan berkurang. Resiko yang dihadapi UMKM akan semakin tinggi apabila aktiva yang kecil menjadikan dana bisnis habis perihal ini yaitu pembayaran wajib kredit, utamanya ketika inflasi serta suku bunga tinggi. Peningkatan inflasi serta suku bunga hendak menjadikan biaya untuk suatu bisnis kian tinggi, hingga bisa berdampak ke kelangsungan bisnis, dan juga pemodalan merupakan tantangan bagi pengembangan suatu usaha UMKM. Dalam Tabel I.1 dapat dilihat bahwa BI Rate, Inflasi dan Kurs rupiah pada tahun 2018-2019 mengalami penurunan namun perkembangan persentase pembiayaan kredit UMKM justru mengalami penurunan. Berbagai penelitian yang sama telah dilakukan seperti yang telah dilakukan oleh Weera Prasertnukul ${ }^{1}$; Farhad Taghizadeh-Hesary ${ }^{1}$. Tujuan penelitian ini adalah untuk mengetahui Faktor BI Rate, Inflasi, dan Kurs Rupiah terhadap pembiayaan kredit UMKM.

Tabel 1. Data BI Rate, Inflasi, Kurs Rupiah dan Perkembangan Kredit UMKM tahun 2011-2019

\begin{tabular}{|c|c|c|c|c|c|}
\hline \multirow{2}{*}{$\begin{array}{l}\text { TAHU } \\
\text { N }\end{array}$} & \multicolumn{5}{|c|}{ VARIABEL PENELITIAN } \\
\cline { 2 - 6 } & $\begin{array}{c}\text { BI } \boldsymbol{R A T E} \\
\mathbf{( \% )}\end{array}$ & $\begin{array}{c}\text { INFLASI } \\
\mathbf{( \% )}\end{array}$ & $\begin{array}{c}\text { KURS } \\
\text { RUPIAH } \\
(\mathbf{R P})\end{array}$ & $\begin{array}{c}\text { UMKM } \\
\text { (Triliun } \\
\text { Rupiah) }\end{array}$ & $\begin{array}{c}\text { PERKEMBANGAN } \\
\text { KREDIT UMKM } \\
(\%)\end{array}$ \\
\hline 2011 & $6.00 \%$ & 129,91 & $9.068,00$ & 38,18 & $\ldots$ \\
\hline 2012 & $5.75 \%$ & 135,49 & $9.670,00$ & 43,867 & $15 \%$ \\
\hline 2013 & $7.50 \%$ & 146,84 & $12.189,00$ & 50,836 & $16 \%$ \\
\hline 2014 & $7.75 \%$ & 119 & $12.440,00$ & 55,977 & $10 \%$ \\
\hline 2015 & $7.50 \%$ & 122,99 & $13.795,00$ & 61,65 & $10 \%$ \\
\hline 2016 & $4.75 \%$ & 126,71 & $13.436,00$ & 71,41333 & $16 \%$ \\
\hline 2017 & $4.25 \%$ & 131,28 & $13.548,00$ & 78,5325 & $10 \%$ \\
\hline 2018 & $6.00 \%$ & 135,39 & $14.481,00$ & 86,05333 & $10 \%$ \\
\hline 2019 & $5.00 \%$ & 139,07 & $13,901,00$ & 91,51167 & $6 \%$ \\
\hline
\end{tabular}

Sumber : www.bi.go.id www.idx.co.id www.pusatdata.kontan.co.id www.bps.go.id 


\section{I.2 Rumusan Masalah}

I.2.1 Bagaimana pengaruh BI Rate terhadap pembiayaan kredit UMKM?

I.2.2 Bagaimana pengaruh Inflasi terhadap pada pembiayaan kredit UMKM?

I.2.3 Bagaimana pengaruh Kurs rupiah terhadap pada pembiayaan kredit UMKM?

I.2.4 Bagaimana pengaruh BI Rate, Inflasi serta Kurs Rupiah secara simultan terhadap pembiayaan kredit UMKM?

\section{KAJIAN LITERATUR}

\section{I.3.1 Suku Bunga BI/ BI Rate}

Pengertian BI Rate menurut Siamat (2010:139) yakni suku bunga bersama tenor 1 bulan yang dipublis BI secara periodik guna waktu tertentu yang berguna selaku sinyal (stance) kebijakan moneter. BI lazimnya hendak meningkatkan BI Rate bila inflasi ke depan diestimasikan melewati target yang ditentukan (www.bi.go.id). Dengan demikian, BI Rate berguna selaku sinyal dari kebijakan moneter, serta mampu dikonklusikan kebijakan moneter Indonesia diasumsikan dalam peningkatan, penurunan ataupun konstan BI Rate (Fajar, 2014).

Hipotesis 1: BI Rate berpengaruh pada pembiayaan kredit UMKM.

\section{I.3.2 Inflasi}

Pengertian Inflasi menurut Sukirno (2011:165) ialah peningkatan harga barang yang sifatnya umum serta kontinu. Inflasi hendak mempengaruhi aktivitas ekonomi secara makro ataupun mikro mencakup aktivitas investasi. Inflasi mengakibatkan pula turunnya daya beli rakyat yang berakibat terhadap turunnya penjualan. Turunnya penjualan yang berlangsung mampu menurunkan return perseroan. Turunnya return yang berlangsung hendak mempengaruhi daya perusahaan guna melunasi angsuran pembiayaan (Suyanto, 2017).

Hipotesis 2: Inflasi berpengaruh pada pembiayaan kredit UMKM.

\section{I.3.3 Kurs Rupiah}

Pengertian Kurs Rupiah menurut Adiningsih, dkk (1998:155) adalah harga rupiah pada mata uang negara lainnya. Perubahan Kurs Rupiah yang fluktuatif berpengaruh terhadap kelancaran usaha. Sebab bila nilai tukar kian melemah dibandingkan nilai tukar mata uang asing, hingga biaya produksi kian naik, bila produsen memakai bahan baku dari impor. Selain itu juga berpengaruh terhadap biaya ekspor. Dengan demikian, nilai tukar berpengaruh terhadap penyaluran pembiayaan. Dibuktikan lewat capaian studi yang 
dilakukan oleh Kusnandar (2012) yang menyatakan nilai tukar uang berdampak positif serta signifikan pada pembiayaan kredit UMKM.

Hipotesis 3: Kurs Rupiah berpengaruh pada pembiayaan kredit UMKM.

\section{I.3.4 UMKM}

Definisi UMKM ialah istilah umum di khazanah ekonomi yang merujuk pada usaha ekonomi produktif yang di miliki perorangan ataupun badan usaha selaras bersama kriteria yang di tetapkan menurut undangundang No.20 tahun 2008 yaitu:

1. Kriteria usaha mikro adalah punya harta bersih paling banyak Rp. 50.000 .000 tak mencakup tanah bangunan lokasi bisnis, ataupun punya capaian penjualan paling banyak Rp.300.000.000.

2. Kriteria usaha kecil punya harta bersih $>$ Rp. 50.000.000 sampai paling banyak Rp. 500.000.000 tak mencakup tanah serta bangunan lokasi bisnis ataupun mempunyai capaian capaian penjualan tahunan > Rp. 300.000.000 hingga paling banyak Rp. 2.500.000.000.

3. Kriteria Usaha Menengah mempunyai harta bersih > Rp. 500.000.000 hingga paling banyak Rp. 10.000.000.000 ataupun mempunyai penjualan tahunan > Rp. 2.500.000.000 sampai paling banyak Rp. 50.000.000.000.

Tabel 2. Definisi Operasional

\begin{tabular}{|c|c|c|c|c|}
\hline Author/Year & Title & Variable & Method & Findings \\
\hline $\begin{array}{c}\text { Weera } \\
\text { Prasertnukul }^{1} \text {, } \\
\text { Donghun Kim }^{2} \text {, } \\
\text { Makoto } \\
\text { Kakinaka }^{3} \\
\text { (2010) }\end{array}$ & $\begin{array}{l}\text { Exchange } \\
\text { rates, price } \\
\text { levels, and } \\
\text { inflation } \\
\text { targeting: } \\
\text { Evidence } \\
\text { from Asian } \\
\text { countries }\end{array}$ & $\begin{array}{l}\text { Exchange rate, } \\
\text { Inflation } \\
\text { Targeting, Pass- } \\
\text { through, } \\
\text { Exchangerate } \\
\text { volatility }\end{array}$ & $\begin{array}{c}\text { Secondary } \\
\text { Data } \\
\text { Analysis }\end{array}$ & $\begin{array}{c}\text { inflation targeting } \\
\text { helped achieve the } \\
\text { primary objective of } \\
\text { price stability through a } \\
\text { decline in exchange rate } \\
\text { pass-through or } \\
\text { volatility, complementing } \\
\text { expected reduction in } \\
\text { inflation. }\end{array}$ \\
\hline $\begin{array}{c}\text { Farhad } \\
\text { Taghizadeh- } \\
\text { Hesary }^{1} \text {, Naoyuki } \\
\text { Yoshino }^{2} \text {, Lisa } \\
\text { Fukuda }^{3} \text {, Ehsan } \\
\text { Rasoulinezhad } \\
(2020)\end{array}$ & $\begin{array}{l}\text { A model for } \\
\text { calculating } \\
\text { optimal } \\
\text { credit } \\
\text { guarantee fee } \\
\text { for small and } \\
\text { medium-sized } \\
\text { enterprises }\end{array}$ & $\begin{array}{l}\text { small and medium- } \\
\text { sized enterprises, } \\
\text { Finance, Credit } \\
\text { guarantee scheme, } \\
\text { Credit guarantee } \\
\text { fee, Credit } \\
\text { constraints }\end{array}$ & $\begin{array}{l}\text { Empirical } \\
\text { analysis, } \\
\text { Secondary } \\
\text { Data } \\
\text { Analysis }\end{array}$ & $\begin{array}{l}\text { effectiveness of CGSs } \\
\text { have been under scrutiny } \\
\text { by scholars, especially } \\
\text { after the negative } \\
\text { impacts of the GFC on } \\
\text { financial systems. }\end{array}$ \\
\hline
\end{tabular}




\section{I.4 Kerangka Konseptual}

Adapun Kerangka Konseptual di studi ini ialah :

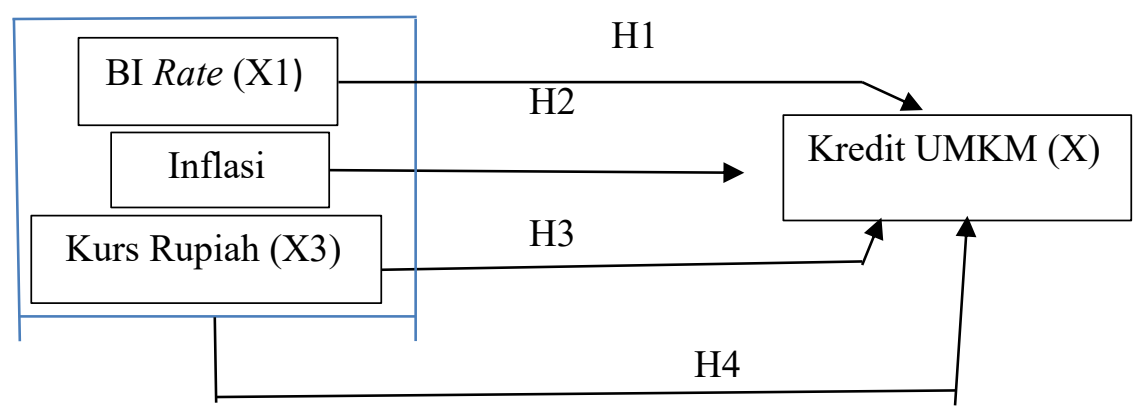

\section{I.5 Hipotesis}

H1: Bi Rate berpengaruh pada pembiayaan kredit UMKM.

H2: Inflasi berpengaruh pada pembiayaan kredit UMKM.

H3: Kurs Rupiah berpengaruh pada pembiayaan kredit UMKM.

H4: BI Rate, Inflasi, Kurs Rupiah berpengaruh pada pembiayaan kredit UMKM.

\section{BAB 3. METODE}

\section{II.1 Pendekatan, Jenis dan Sifat Penelitian}

Penelitian ini merupakan penelitian explanatory research yang bermaksud menjabarkan korelasi kausal antar variabel lewat uji hipotesis serta dilakukan lewat pendekatan analisis deskriptif. Jenis penelitian yakni penelitian kuantitatif dengan mengangkat fakta, kondisi, variabel, serta kejadian yang berlangsung. Sifat penelitian ini yaitu eksplanatori yang merupakan penelitian sistematis dan ilmiah dengan tujuan mendeskripsikan kaitan antara variabel.

\section{2 Tempat dan Waktu Penelitian}

Peneliti mengumpulkan data BI Rate, Kurs Rupiah, Inflasi dan pembiayaan kredit UMKM dengan menggunakan Situs www.bi.go.id, www.idx.co.id, www.sumberdata.kontan.co.id, www.bps.go.id Waktu penelitian dimulai dari Oktober 2019.

\section{3 Populasi dan Sampel}

Populasi di studi ini yakni nasabah kredit UMKM yang telah mendapatkan pembiayaan kredit di Seluruh Indonesia. Data yang diambil yaitu periode 2011-2019 yaitu sebanyak 9 Tahun. Teknik 
penghimpunan data populasi dilakukan dengan pendekatan data berkala (time series) dengan mengunakan data skala tahunan.

\section{4 Jenis dan Sumber Data}

Jenis data yang digunakan yakni data kuantitatif. Sumber data penelitian ini yakni data sekunder. Menurut Tohirin (2013:2) studi yang berusaha membuat persepsi individu yang diteliti dengan rinci dan diciptakan lewat kata, gambaran holistik (menyeluruh serta mendalam) serta kompleks. Sesuai Zuldafrial (2012:46) sumber data ialah asal subjek darimana data mampu didapat. Sumber data penelitian berasal dari www.bi.go.id, www.idx.co.id, www.sumberdata.kontan.co.id, www.bps.go.id

\section{II.5 Identifikasi dan Definisi Operasional Variabel Penelitian}

Variabel yang dipakai di studi ini yakni dependent variable serta independent variable. Dependent variable ialah variabel yang dipengaruhi ataupun familiar pula selaku variabel yang jadi akibat terdapatnya independent variable. Sedangkan independent variable yakni variabel yang jadi sebab terdapatnya transformasi dependent variable. BI Rate dimaknai selaku suku bunga kebijakan yang merepresentasikan perilaku ataupun stance kebijakan moneter yang ditentukan BI serta di umumkan pada publik. Inflasi dimaknai selaku kecondongan berlangsungnya kenaikan harga produk secara menyeluruh hingga berlangsung turunnya daya beli uang. Kurs Rupiah ialah harga dari sebuah mata uang di mata uang negara lainnya, contoh nilai rupiah selepas dikonversi di dolar AS. UMKM ialah bisnis yang memiliki kedudukan esensial perekonomian Indonesia, baik dari segi lapangan kerja yang terbentuk ataupun total bisnisnya.

\section{II.6 Teknik Analisis Data}

\section{II.6.1 Uji Asumsi Klasik}

Uji Asumsi klasik wajib dicukupi pada analisis regresi linier berganda pada hipotesis studi. Jenisjenis uji asumsi Klasik.

\section{II.6.1.1 Uji Normalitas}

Uji Normalitas bermaksud guna menguji apa di model regresi, variabel residual ataupun pengganggu mempunyai distribusi normal. Uji t serta $\mathrm{F}$ menjabarkan nilai residual mengiringi distribusi normal. Bila asumsi ini dilangga hingga pengujian statistik jadi tak valid guna total sampel kecil. Terdapat 2 cara guna melihat apa residual berdistribusi normal ataupun tak dilaksanakan memakai pengujian statistik serta analisis grafik. Guna menguji apa data berdistribusi normal ataupun tak dilaksanakan pengujian statistic Kolmogorov-Smirnov. Residual berdistribusi normal bila punya angka signifikan >0,05 (Imam Ghozali, 2011: 160-165).

II.6.1.2 Uji Multikolinearitas 
Menurut Imam Ghozali (2011: 105-106) pengujian multikolinieritas bermaksud guna menguji apa model regresi dijumpai terdapatnya hubungan antar independent variable dalam sebuah penelitian. Guna menguji multikolinieritas yakni lewat cara meninjau angka VIF tiap independent variable, bila angka VIF $<10$, hingga dikonklusikan data bebas dari gejala multikolinieritas.

\section{II.6.1.3 Uji Autokolerasi}

Uji autokorelasi ialah pengujian yang dipakai guna meninjau berlangsungnya hubungan antara sebuah periode $\mathrm{t}$ bersama periode sebelumnya bersama rumus $\mathrm{t}-1$, yang mencakup uji terdapatnya dampak 1 variabel bersama variabel lain. Di studi ini guna menguji terdapat tidaknya gejala autokorelasi memakai uji Durbin-Watson (DW test).

\section{II.6.1.4 Uji Heterokedastisitas}

Uji Heterokedastisitas bermaksud guna menganalisis apa di model regresi berlangsung ketidaksepadanan variance dari residual 1 observasi ke observasi lainnya. Sejumlah cara yang mampu dilaksanakan guna melaksanakan pengujian heterokedastisitas yaitu dengan pengujian grafik plot, harvey, white, ARCH serta glejser.

\section{II.7 Model Penelitian}

Model studi yang dipakai yakni analisis linier berganda. Model regresi analisis linier berganda bersama rumus:

$\mathrm{Y}_{1}=\alpha+\mathrm{B}_{1} \mathrm{X}_{1}+\mathrm{B}_{2} \mathrm{X}_{2}+\mathrm{B}_{3} \mathrm{X}_{3}+\mathrm{B}_{4} \mathrm{X}_{4}+\mathrm{e}$

Dimana:

$\mathrm{Y}_{1}=$ Pembiayaan kredit UMKM

$\alpha=$ Konstanta

$\mathrm{b}_{1}, \mathrm{~b}_{2}, \mathrm{~b}_{3}, \mathrm{~b}_{4}=$ Koefisien Regresi

$\mathrm{X}_{1}=\mathrm{BI}$ Rate

$\mathrm{X}_{2}=$ Inflasi

$\mathrm{X}_{3}=$ Kurs Rupiah

$\mathrm{e}=$ Standar error

\section{II.8 Uji Hipotesis Penelitian}

\section{II.8.1 Koefisien Determinasi}

Koefisien determinasi di regresi linear kerap dimaknai selaku seberapa besarkah daya seluruh independent variable guna menjabarkan variance dari dependent variable.

II.8.2 Uji Hipotesis parsial (Uji t) 
Sesuai Ghozali (2016:97), bila independent variable lainnya diasumsikan stabil hingga guna meninjau efek dari satu independent variable pada dependent variable dipakai Uji t.

II.8.3 Uji Hipotesis simultan (Uji F)

Sesuai Ghozali (2016:97), dipakai guna menunjukkan apa independent variable secara bersamaan memiliki dampak pada dependent variable.

\section{HASIL DAN PEMBAHASAN}

\section{III.1 Uji Asumsi Klasik}

Uji asumsi klasik dipakai guna menguji dan memperlihatkan apakah model regresi pada penelitian layak dipakai atau tidak. Di studi ini digunakan model analisis regresi linier berganda. Adapun syarat menggunakan persamaan regresi linier berganda yaitu melewati uji asumsi klasik.

\section{III.1.1 Uji Normalitas}

3
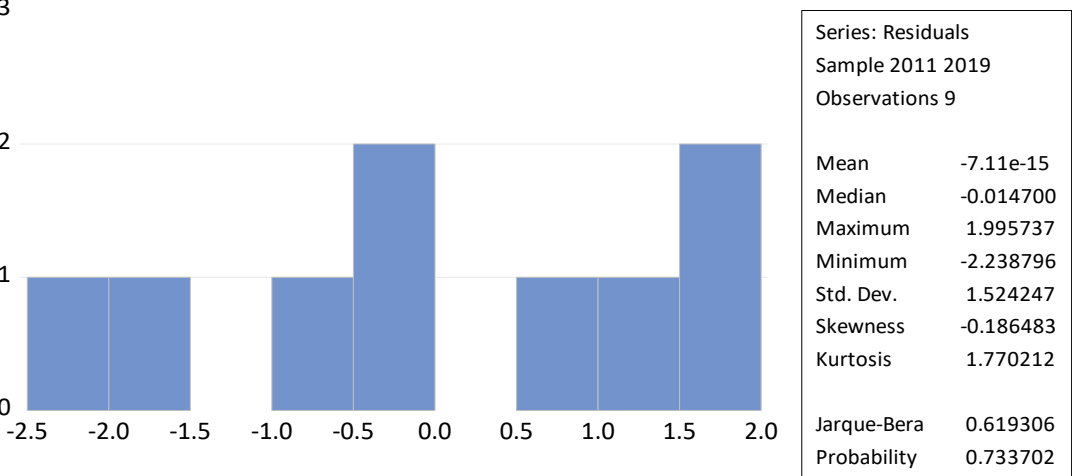

Gambar III.1 Uji Normalitas Histogram

Dari gambar III.1 dapat disimpulkan data telah berdistribusi normal karena memiliki nilai probabilitas $0,733702>0,05$.

\section{III.1.2 Uji Multikolinearitas}

Tabel III.1 Pengujian Multikolinearitas

\begin{tabular}{cccc}
\hline \hline & \multicolumn{2}{c}{ Coefficient } & Uncentered \\
Variable & Variance & VIF & VIF \\
\hline \hline C & 4450.474 & 10775.01 & NA \\
LOG(BIRATE) & 10.47860 & 203.4651 & 1.050009
\end{tabular}




\begin{tabular}{cccc} 
LOG(IHK) & 116.4369 & 6714.019 & 1.034409 \\
LOG(KURS) & 17.12321 & 3681.351 & 1.026008 \\
\hline
\end{tabular}

Uji data ini menunjukkan pada variabel bebas tidak saling berkolerasi karena mempunyai angka VIF $<10$. Hingga mampu dikonklusikan data terbebas dari gejala multikolinearitas.

\section{III.1.3 Uji Autokolerasi}

\section{Tabel III.2 Pengujian Autokolerasi}

Breusch-Godfrey Serial Correlation LM Test:

Null hypothesis: No serial correlation at up to 2 lags

\begin{tabular}{llll}
\hline \hline F-statistic & 0.981005 & Prob. F(2,3) & 0.4701 \\
Obs*R-squared & 3.558656 & Prob. Chi-Square(2) & 0.1688 \\
\hline \hline
\end{tabular}

Dilihat dari tabel III.2 dapat disimpulkan data terbebas dari gejala autokolerasi dikarenakan angka Probabilitas Chi-Square yakni 0,1688 $>0,05$.

\section{III.1.4 Uji Heteroskedastisitas}

\section{Tabel III.3 Uji Heterokedastisitas}

Heteroskedasticity Test: ARCH

\begin{tabular}{llll}
\hline \hline F-statistic & 0.445121 & Prob. F(1,6) & 0.5295 \\
Obs*R-squared & 0.552506 & Prob. Chi-Square(1) & 0.4573 \\
\hline \hline
\end{tabular}

Dilihat dari Tabel III.3 Uji Heteroskedastisitas dengan metode uji ARCH, Nilai Obs*R-squared 0,4573 > 0,05 yang menandakan tak berlangsung gejala Heteros.

\section{III.2 Analisis}

\section{III.2.1 Regresi Linier Berganda}

Tabel III.4 Regresi Linier Berganda

\begin{tabular}{crrrr}
\hline \hline & Coefficien & & & \\
Variable & $\mathrm{t}$ & Std. Error & t-Statistic & Prob. \\
\hline \hline C & 109.1373 & 66.71187 & 1.635950 & 0.1628 \\
LOG(BIRATE) & 0.302164 & 3.237067 & 0.093345 & 0.9293 \\
LOG(IHK) & -11.83547 & 10.79059 & -1.096832 & 0.3227 \\
LOG(KURS) & -4.281380 & 4.138020 & -1.034644 & 0.3483 \\
\hline \hline
\end{tabular}


Penjebaran Statistik Deskriptif Analisis Regresi Linier Berganda:

1. Bersama asumsi Inflasi dan Kurs tetap, hingga tiap kenaikan BI Rate yakni $1 \%$ hendak menaikkan Pembiayaan Kredit UMKM yakni 0,302164 \%.

2. Bersama asumsi BI Rate dan Kurs tetap, hingga tiap kenaikan Inflasi sebesar $1 \%$ hendak membuat turun Pembiayaan Kredit UMKM yakni 11,83547 \%.

3. Bersama asumsi BI Rate serta Inflasi tetap, hingga tiap kenaikan Kurs yakni 1\% hendak membuat turun Pembiayaan Kredit UMKM yakni 4,281380\%.

\section{III.2.2 Koefisien Determinasi}

\section{Tabel III.5 Koefisien Determinasi}

\begin{tabular}{lrll}
\hline \hline R-squared & 0.312549 & Mean dependent var & 10.18914 \\
Adjusted R-squared & -0.099922 & S.D. dependent var & 1.838377 \\
S.E. of regression & 1.928037 & Akaike info criterion & 4.451985 \\
Sum squared resid & 18.58664 & Schwarz criterion & 4.539640 \\
Log likelihood & -16.03393 & Hannan-Quinn criter. & 4.262825 \\
F-statistic & 0.757747 & Durbin-Watson stat & 1.482949 \\
Prob(F-statistic) & 0.563877 & & \\
\hline \hline
\end{tabular}

\section{III.2.2.1 Koefisien Determinasi Berganda}

Pada tabel III.5 diatas menunjukkan angka koefisien determinasi berganda di eviews 11 sepadan bersama aplikasi lain yakni diberi label R-Square. Di tabel di atas mampu ditinjau R-Square yakni 0,312549 yang bermakna segolongan dependent variable di model tidak mampu menjabarkan independent variable. Sedang kelebihannya dijabarkan variabel lainnya di luar model yang tak dikaji.

\section{III.2.2.2 Adjusted R Square}

Angka adjusted R Square maknanya angka R Square yang sudah terbenahi oleh angka standar error. Ditabel III.5 Adjusted R Square yakni -0,099922. Sedang angka standard error model regresi 1.928037 diperlihatkan lewat label S.E of regression. Angka standar error ini $>$ angka standar deviasi independent variable yang diperlihatkan lewat label "S.D. dependent var" yakni 1.838377 yang dimaknai model regresi tak valid selaku model dependent variabel.

\section{III.2.3 Uji F}

Tabel III.6 Pengujian F

\begin{tabular}{lrll}
\hline \hline R-squared & 0.312549 & Mean dependent var & 10.18914 \\
Adjusted R-squared & -0.099922 & S.D. dependent var & 1.838377
\end{tabular}




\begin{tabular}{lrll} 
S.E. of regression & 1.928037 & Akaike info criterion & 4.451985 \\
Sum squared resid & 18.58664 & Schwarz criterion & 4.539640 \\
Log likelihood & -16.03393 & Hannan-Quinn criter. & 4.262825 \\
F-statistic & 0.757747 & Durbin-Watson stat & 1.482949 \\
Prob(F-statistic) & 0.563877 & & \\
\hline \hline
\end{tabular}

Uji simultan ini dilaksanakan lewat memperbandingkan F hitung serta F tabelnya. Diketahui N1= variabel1 maka N1=3-1 didapat N1=2. Dan Rumus N2=jumlah sampel-variabel maka N2=9-3 didapat N2=6. Maka besarnya F Tabel adalah 5,79. Dengan hasil F-statistic bernilai 0,757747 maka Fhitung $(0,757747)<$ Ftabel $(5,79)$ dan Prob(F-statistic) $>0,05$ hingga Ha ditolak yang maknanya BI rate, Inflasi, serta Kurs rupiah secara simultan tak berpengaruh pada pembiayaan kredit UMKM.

\section{III.2.4 Uji t}

\section{Tabel III.7 Uji t}

\begin{tabular}{crrrr}
\hline \hline & Coefficien & & & \\
Variable & $\mathrm{t}$ & Std. Error & t-Statistic & Prob. \\
\hline \hline C & 109.1373 & 66.71187 & 1.635950 & 0.1628 \\
LOG(BIRATE) & 0.302164 & 3.237067 & 0.093345 & 0.9293 \\
LOG(IHK) & -11.83547 & 10.79059 & -1.096832 & 0.3227 \\
LOG(KURS) & -4.281380 & 4.138020 & -1.034644 & 0.3483 \\
\hline \hline
\end{tabular}

Besarnya $t$ tabel di probabilitas 0,05 bersama taraf pengujian signifikan 2 arah serta df 6 yakni 2,44691. Intrepertasi capaian pengujian parsial dari tabel diatas adalah sebagai berikut:

1. Dari tabel III.7 menunjukkan secara parsial hasil pengujian variabel BI rate pada pembiayaan kredit UMKM. Diketahui t hitung BI rate sebesar 0,093345 dan t tabel sebesar 2,44691, artinya BI rate tak berpengaruh serta tak signifikan pada pembiayaan kredit UMKM.

2. Dari tabel III.7 menunjukkan secara parsial hasil pengujian variabel Inflasi terhadap pembiayaan kredit UMKM. Diketahui t hitung Inflasi yakni -1,096832 serta t tabel yakni 2,44691, artinya Inflasi tak berpengaruh serta tak signifikan pada pembiayaan kredit UMKM.

3. Dari tabel III.7 menunjukkan secara parsial hasil pengujian variabel Kurs rupiah terhadap pembiayaan kredit UMKM. Diketahui t hitung Kurs rupiah yakni -1,034644 serta t tabel yakni 2,44691, artinya Kurs rupiah tak berpengaruh serta tak signifikan pada pembiayaan kredit UMKM.

\section{III.3 Pembahasan}

\section{III.3.1 Pengaruh BI rate pada pembiayaan kredit UMKM}


Dari capaian pengolahan data memakai Eviews11 melalui pengujian $t$ hipotesis yang memperlihatkan angka thitung yakni $0,093345<\mathrm{t}$ tabel yakni 2,44691. Artinya tidak terdapat pengaruh signifikan BI rate pada pembiayaan kredit UMKM. BI Rate berpengaruh negative signifikan yang menunjukkan hubungan tidak searah antar variabel BI rate dan pembiayaan kredit UMKM, yang maknanya $\mathrm{BI}$ rate naik hingga penyaluran pembiayaan UMKM hendak menurun, serta kebalikannya Ketika BI rate turun hingga pembiayaan UMKM hendak naik. Capaian studi ini selaras bersama capaian studi yang dilaksanakan Jayanti dan Anwar (2016) yang menjabarkan BI Rate tidak ada dampak signifikan pada pembiayaan kredit UMKM.

\section{III.3.2 Pengaruh Inflasi pada pembiayaan kredit UMKM}

Sesuai capaian pengolahan data menggunakan Eviews11 melalui pengujian $\mathrm{t}$ hipotesis yang memperlihatkan $\mathrm{t}$ hitung yakni $-1,096832<\mathrm{t}$ tabel yakni 2,44691. Artinya tidak terdapat pengaruh signifikan Inflasi pada pembiayaan kredit UMKM. Hal ini dibuktikan dengan kian tinggi tingkat Inflasi hingga hendak mengalami kesulitan terhadap pembiayaan UMKM yang dilakukan Bank. Capaian studi ini di dukung studi yang dilaksanakan Nurhidayah dan Isvandiari (2016) yang menjabarkan inflasi tak berpengaruh pada pembiayaan kredit UMKM.

\section{III.3.3 Pengaruh Kurs Rupiah terhadap pembiayaan kredit UMKM}

Dari capaian pengolahan data menggunakan Eviews1 1 melalui pengujian $\mathrm{t}$ hipotesis yang memperlihatkan angka thitung yakni $-1,034644<\mathrm{t}$ tabel yakni 2,44691. Maknanya tak terdapat pengaruh signifikan Kurs Rupiah pada pembiayaan UMKM.Kurs Rupiah ialah variabel sifatnya nasional yang dampaknya tidak amat besar dikegiatan perekonomian lokal seperti Sumatra Utara. Capaian studi ini selaras bersama capaian studi yang dilaksanakan Winarsih (2015) yang menjabarkan Kurs rupiah tak berpengaruh pada pembiayaan kredit UMKM.

\section{KESIMPULAN}

\section{IV.1 Kesimpulan}

Konklusi yang diperoleh dari capaian studi ini yaitu:

1. Secara parsial BI Rate tidak berdampak serta tak signifikan pada pembiayaan kredit UMKM.

2. Secara parsial Inflasi tak berdampak dan tidak signifikan pada pembiayaan kredit UMKM.

3. Secara parsial Kurs Rupiah tidak berpengaruh serta tak signifikan pada pembiayaan kredit UMKM.

4. Secara simultan BI Rate, Inflasi serta Kurs rupiah tidak berpengaruh pada pembiayaan kredit UMKM. 


\section{REFRENSI}

Laporan Kredit UMKM (2011-2019) www.bps.go.id

Statistik Pertumbuhan BI Rate (2011-2019) www.pusatdata.kontan.co.id

Statistik Pertumbuhan Inflasi (2011-2019) www.bi.go.id

Statistik Pertumbuhan Kurs Rupiah (2011-2019) www.bi.go.id

(Jayanti 2016) Devi, W. Lailia, and E. F. Cahyono. 2020. “Analisis Pengaruh Sertifikat Bank Indonesia (Sbi), Sertifikat Bank Indonesia Syariah (Sbis), Inflasi Dan Bi Rate Terhadap Penyaluran Dana Ke Sektor Umkm Oleh Perbankan Syariah Di Indonesia.” Jurnal Ekonomi Syariah Teori dan Terapan 7(3): 499.

HASANAH, Nuramalia.et al. 2017. "Pengaruh Tingkat Suku Bunga , Inflasi Dan Rasio Kecukupan Modal Terhadap Penyaluran Kredit UMKM Oleh Bank Umum Di Indonesia Tahun 2007 - 2013." Jurnal Informasi Akuntansi dan Keuangan (INFAK) 3(2): 106-13.

Jayanti, Sri Delasmi. 2016. "Pengaruh Inflasi Dan BI Rate Terhadap Pembiayaan Usaha Mikro Kecil Dan Menengah (Studi Kasus Pada Bank Umum Syariah)." I-Economics 2(2): 86-105.

Kusnandar, E. 2013. “Analisis Faktor-Faktor Yang Mempengaruhi Pemberian Kredit Umkm Oleh Perbankan Di Indonesia." : 1-70.

Rosa, Yenni Del. 2019. "Pengaruh Inflasi Dan Suku Bunga Terhadap Omset UMKM Di Kota Padang." Jurnal Berkala Ilmiah Efisiensi 19(01): 133-45.

Suci, Yuli Rahmini, Sekolah Tinggi, and Ilmu Ekonomi. 2017. "Perkembangan UMKM (Usaha Mikro Kecil Menengah) Di Indonesia.” Jurnal Ilmiah fakultasi Ekonomi 6(1): 51-58.

Wahiddudin, M. 2018. "Pengaruh Inflasi, Non Performing Finacing (Npf) Dan Bi Rate Terhadap Pembiayaan Usaha Mikro Kecil Dan Menengah (Umkm) Pada Bank Umum Syariah 2012-2017.” Al Amwal 1(1): 76-89.

Yustini, T. 2015. "Pengaruh Suku Bunga, Jumlah Perusahaan Dan Pertumbuhan Ekonomi Terhadap Penyaluran Kredit Modal Kerja Bagi Umkm Di Sumatera Selatan.” Jurnal Keuangan dan Perbankan 19(3): 463-74.

(Rosa 2019)Rosa, Yenni Del. 2019. "Pengaruh Inflasi Dan Suku Bunga Terhadap Omset UMKM DiKota Padang."Jurnal Berkala Ilmiah Efisiensi 19(01): 133-45.

(Suci, Tinggi, and Ekonomi 2017)Suci, Yuli Rahmini, Sekolah Tinggi, and Ilmu Ekonomi. 2017. "Perkembangan UMKM (Usaha Mikro Kecil Menengah) Di Indonesia." Jurnal Ilmiah fakultasi Ekonomi 6(1): 51-58.

(HASANAH 2017)HASANAH, Nuramalia.et al. 2017. "Pengaruh Tingkat Suku Bunga, Inflasi Dan Rasio Kecukupan Modal Terhadap Penyaluran Kredit UMKM Oleh Bank Umum Di Indonesia Tahun 2007 - 2013.” Jurnal Informasi Akuntansi dan Keuangan (INFAK) 3(2): 106-13.

(Devi and Cahyono 2020)Devi, W. Lailia, and Eko Fajar Cahyono. 2020. "Analisis Pengaruh Sertifikat Bank Indonesia (Sbi), Sertifikat BI Syariah (Sbis), Inflasi Dan Bi Rate Terhadap Penyaluran Dana Ke Sektor Umkm Oleh Perbankan Syariah DiIndonesia.” Jurnal Ekonomi Syariah Teori dan Terapan 7(3): 499. 
(Wahiddudin 2018) Wahiddudin, M. 2018. "Pengaruh Inflasi, NPF Dan Bi Rate Terhadap Pembiayaan UMKM Pada BUS 2012-2017.” Al Amwal 1(1): 76-89.

(Yustini 2015)Yustini, Tien. 2015. "Pengaruh Suku Bunga, Jumlah Perusahaan Dan Pertumbuhan Ekonomi Terhadap Penyaluran Kredit Modal Kerja Bagi Umkm Di Sumatera Selatan.” Jurnal Keuangan dan Perbankan 19(3): 463-74. 